\title{
Transversus Nuchae Muscle Fused with Risorius Muscle: A Case Report
}

\author{
Músculo Transverso de la Nuca Fusionado con Músculo Risorius: Informe de un Caso
}

Trajche Jovanovski; Nejc Umek \& Erika Cvetko

JOVANOVSKI, T.; UMEK, N. \& CVETKO, E. Transversus nuchae muscle fused with risorius muscle: A case report. Int. J. Morphol., 38(5):1208-1211, 2020.

SUMMARY: Facial muscles are known to have a variable anatomy. Such anatomical variations can affect facial expressions. A natural smile is produced by contracting several muscles of facial expression, including the muscles invested in the superficial musculoaponeurotic system. Change in the width of the mouth on smiling is a known iatrogenic complication affecting the risorius muscle when using Botulinum Neurotoxin as a non-invasive treatment for masseteric hypertrophy. Also damage to the risorius muscle, with consequent clinical deficits, is a common surgical complication in facial aesthetic, oncologic and other head and neck procedures such as parotidectomy and rhytidectomy. Hence, a thorough knowledge of muscle anatomy, particularly its potential variations, is critical in reducing the associated operative morbidity. Accordingly, we report an unusual variation of the transversus nuchal muscle fused with the risorius muscle noted in an 83-year-old female body cadaver.

KEY WORDS: Anatomical variation; Transversus nuchal muscle; Risorius muscle; Facial expression; Rhytidectomy.

\section{INTRODUCTION}

The embryologic development of the head mimetic muscles is rather complex. Accordingly, a considerable variation in their anatomy is to be expected. The transversus nuchal muscle is inconsistently present in the occipital region in the same plane as the muscles of facial expression and is one of the muscles constituting the superficial musculoaponeurotic system (Lei et al., 2010). It originates from the external occipital protuberance or from the superior nuchal line and frequently inserts with the posterior auricular muscle, but may blend with the posterior edge of the sternocleidomastoid (Standring, 2016).

The risorius muscle normally originates in the superficial fascia above the masseter muscle and attaches to the central tendon region known as the modiolus (Lightoller, 1925). It retracts the corner of the mouth when contracted. Anatomical consideration of the transversus nuchal and the risorius muscle could prove resourceful, specifically while planning certain clinical procedures such as facelift surgery, facial reconstruction surgery, as well as masseter muscle hypertrophy Botulinum Neurotoxin
(BoNT) treatment (Liew \& Dart, 2008; Lei et al.; Bae et al.; Matsuine et al., 2019). We report an anatomic variation, not yet described in literature - a transversus nuchal muscle fused with risorius muscle inserting on to the modiolus.

\section{CASE REPORT}

During the head and neck dissection of an 83-year old female formaldehyde-embalmed body, as part of a training session for maxillofacial surgeons, an unusually long transversus nuchal muscle fused in the parotideomasseteric region with the risorius mucle was observed bilaterally. The skin and subcutaneous tissue were carefully dissected using magnifying lenses $(4 \mathrm{x})$. There were no signs of previous trauma or surgical scars on the face and neck (Fig. 1). On the right side the transversus nuchal muscle originated with two narrow bellies, the anterior one being inserted to the sternocleidomastoid fascia attaching 
to the mastoid process, and the posterior one to the trapezius muscle fascia and the lateral part of the superior nuchal line. The muscle descended obliquely downward and anteriorly over the sternocleidomastoid muscle, continuing horizontally below the auricle to the cheek, and inserting to the modiolus. On the left side, the transversus nuchal muscle originated with two narrow bellies from the trapezius muscle and its fascia, attaching to the lateral part of the superior nuchal line. It continued horizontally to the cheek region, inserting to the modiolus. The length of the muscle was $16.4 \mathrm{~cm}$ on the right side and $15.6 \mathrm{~cm}$ on the left side. The width of both muscles ranged from $2 \mathrm{~mm}$ in the retroauricular part to $12 \mathrm{~mm}$ in the parotideomasseteric region. The insertion to the modiolus was in close relation to the fibres of the platysma muscle on both sides.

On the right side, the buccal part of the unusually long transversus nuchal muscle received innervation from the buccal branch of the facial nerve (CN VII) (Fig. 1a) suggesting that the anterior part of the muscle resembles the risorius muscle. We could not confirm the innervation of the buccal part of the left muscle owing to the difficulty of identifying the thin nerves in the surrounding fibrous tissue in formaldehyde fixed cadavers.

The transversus nuchal muscle coursed close to the sensory nerves of the occipital region. On the right side, it passed between two branches of the minor occipital nerve bifurcating just below the muscle and superficial to the great auricular nerve. On the left side, the transversus nuchal muscle passed superficially to the minor occipital nerve and between two branches of the great auricular nerve, bifurcating just below the muscle. We could not confirm the innervation of the posterior part of the transversus nuchal muscle on both sides.
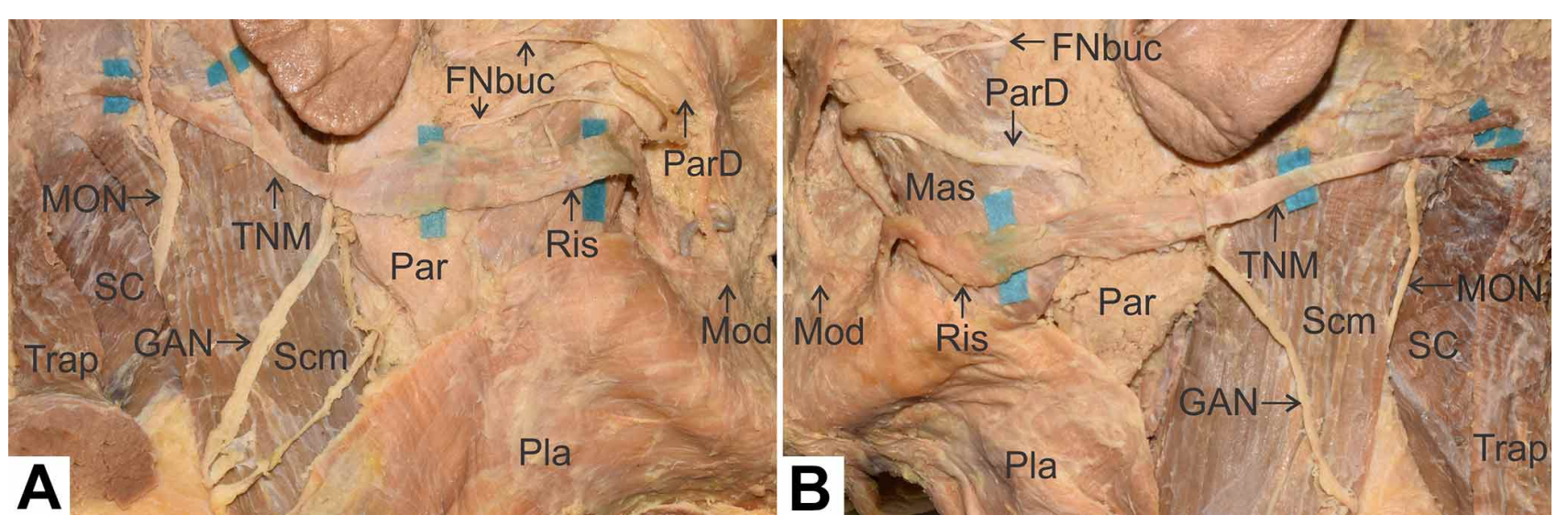

Fig. 1. Superficial dissection of the right (A) and the left (B) side of the head and neck. TNM - transversus nuchae muscle; Ris - risorius muscle; Par - parotid gland; ParD - parotid duct; FNbuc - facial nerve, buccal branch; Mas - masseter muscle; Scm - sternocleidomastoid muscle; SC - splenius capitis muscle; Trap - trapezius muscle; Pla - platysma muscle; MON - minor occipital nerve; GAN - great auricular nerve; Mod - modiolus.

\section{DISCUSSION}

We report a variant, not yet described - a bilateral unusual course of the transversus nuchal muscle fused with the risorius muscle. The transversus nuchal muscle is a facial muscle in the occipital region that is inconsistently present and has been rarely described (Watanabe et al., 2017). It was first described in 1865 by Schultze (1865). Different names have been used for the muscle: occipitalis minor (Bergman et al., 1988), occipital transversus muscle (Bergman et al.) or posterior platysma or platysma occipitalis (Huber, 1930).

The occurrence of the transversus nuchal muscle is variable, with reported incidence ranging from $32.2 \%$ (Watanabe et al.) to $72 \%$ (Schultze, 1865). However, the small number of reports and the small sample size make it difficult to compare the frequency of occurrence of the transversus nuchal muscle. In the case presented, the transversus nuchal muscles were dissected bilaterally. According to data from the literature, bilateral occurrence of the muscle seems more frequent (Lei et al.). On the right side, the anterior part of the unusually long transversus nuchal muscle was innervated from buccal branches of the facial nerve suggesting that the anterior part of the muscle resembles the risorius muscle. Additionally, the insertion of the muscle into the modiolus was typical for the risorius muscle, which arises from the parotid fascia and the fascia surface of the masseter muscle (Bae et al.).

The transversus nuchal muscle lies close to the sensory nerves in the occipital region. On the left, the minor occipital nerve runs superficial to the muscle while on the right side, the muscle coursed between the superficial and 
deep branch of the minor occipital nerve. The great auricular nerve passed on the right superficial to the muscle while on the left muscle run between two branches of the great auricular nerve. Similar to our findings, Watanabe et al. and Schmidt (1982) reported a variable relationship of sensory nerves in occipital region to transversus nuchal muscle.

The innervation pattern of the transversus nuchal muscle has rarely been studied. In the case presented, on the right side, the innervation of the anterior part of the muscle resembling the risorius muscle by the buccal branches of the facial nerve was clearly demonstrated. Schmidt described supply by the sensory nerves anastomosed with branches of the facial nerve: the anterior branch of the great auricular nerve, connected by anastomosis to the inferior buccal branch of the facial nerve; as well as the posterior branch of the great auricular nerve, connected by anastomosis to the posterior auricular branch of the facial nerve.

The facial musculature is derived from the mesenchyme of the second pharyngeal arch and is innervated by the facial nerve. The premuscular facial masses are formed between the 6 th and 7 th week of embryologic development. The migration of the differentiating premyoblasts and early myoblasts proceed from the region of the second pharyngeal arch in multiple sheet-like laminae. The superficial lamina spreads from a location caudal to the external acoustic meatus in all directions forming the temporal, occipital, cervical, and mandibular lamina. These laminae of mesenchymal origin give rise to the superficial mimetic muscles and fasciae (superficial layer of the temporal fascia, epicranial aponeurosis, and the superficial musculoaponeurotic system (SMAS) (De la Cuadra-Blanco et al., 2013). The observed anatomical variation could be a consequence of the fusion of the occipital lamina and the mandibular lamina (Som \& Naidich, 2013).

Safe and rational surgical treatments are premised on precise understanding of the relevant anatomy, including potential variations. During facelift procedures, the SMAS is surgically facilitated by tightening and suspending the facial muscles through various flap dissection approaches (Warren et al., 2011). Bae et al. highlighted the potential risk of iatrogenic injury to the risorius muscle as a result of flap dissection during facelift surgery. The transversus nuchal muscle and risorius muscle variant in our case could be accidentally cut as soon as the initial incision for rhytidectomy is made.

The most popular neuromuscular free flaps for facial reanimation are the pectoralis minor, the latissimus dorsi, and the gracilis flap (Bianchi et al., 2012). Before facial reconstructive surgery, vectors are marked to represent the lines of pull of the zygomaticus major and risorius muscles when producing a symmetric smile, with the assumption that all individuals possess the same number and position of facial muscles (Matsumine et al., 2019). A risorius muscle variant as described in our case would require a modified approach due to its uncommon origin from the mastoid process and the trapezius muscle fascia.

BoNT injection into the masseter muscle as a noninvasive treatment for masseteric hypertrophy often affects the risorius muscle and causes an iatrogenic change in the facial expression, with the most frequently reported change being a reduction in the width of the mouth on smiling (Bae et al.). This complication could be exacerbated in the described anatomical variant due to the larger risorius muscle and its position in relation to the masseter muscle. In facial nerve palsy, hypofunctional asymmetry may result and can require BoNT injection of the same muscle groups on the normofunctional side. Analysing the expressions of the normofunctional side may provide guide as to where to inject BoNT such that it may include the risorius muscle. Our case report thus may also provide valuable information in planning such injection sites (Kim et al., 2015).

In summary, the reported anatomical variation provides additional reference data for surgeons when planning or performing procedures such as facial reanimation, reconstruction, and cosmetic surgeries in the maxillofacial region. Furthermore, it gives an additional point of consideration when planning a BoNT injection into the masseter muscle for the treatment of masseteric hypertrophy.

\section{ACKNOWLEDGEMENTS}

We are grateful to Ivan Blazinovic for the dissection work, Stanko Kristl and Friderik Stendler for technical assistance, Natasa Pollak Kristl for the figure labelling, and to Dr. Chiedozie K Ugwoke for manuscript proofreading. The donor of the body used in the study is respectfully acknowledged. We would also like to thank the Slovenian Research Agency for financial support within the framework of the Program Group P3-0043.

JOVANOVSKI, T.; UMEK, N. \& CVETKO, E. Músculo transverso de la nuca fusionado con músculo risorio: Informe de un caso. Int. J. Morphol., 38(5):1208-1211, 2020.

RESUMEN: Los músculos faciales tienen una anatomía variable. Tales variaciones anatómicas pueden afectar las expresiones faciales. Una sonrisa natural se produce al contraer varios 
músculos de la expresión facial, incluidos los músculos invertidos en el sistema musculoaponeurótico superficial. El cambio en el ancho de la boca al sonreír es una complicación iatrogénica conocida, que afecta el músculo risorio cuando se usa la neurotoxina botulínica como un tratamiento no invasivo para la hipertrofia masterérica. Además, el daño al músculo risorio, con los consecuentes déficits clínicos, es una complicación quirúrgica común en la estética facial, oncológica y otros procedimientos de cabeza y cuello, como la parotidectomía y la ritidectomía. Por lo tanto, un conocimiento profundo de la anatomía muscular, particularmente sus posibles variaciones, es crítico para reducir la morbilidad operativa asociada. En consecuencia, informamos una variación inusual del músculo transverso de la nuca fusionado con el músculo risorio, observado en un cadáver de cuerpo femenino de 83 años.

PALABRAS CLAVE: Variación anatómica; Músculo transverso de la nuca; Músculo Risorius; Expresión facial; Ritidectomía.

\section{REFERENCES}

Bae, J. H.; Lee, J. H.; Youn, K. H.; Hur, M. S.; Hu, K. S; Tansatit ,T. \& Kim, H. J. Surgical consideration of the anatomic origin of the risorius in relation to facial planes. Aesthet. Surg. J., 34(7):NP43-9, 2014.

Bergman, R.; Thompson, S. A.; Afifi, A. K. \& Saadeh, F. A. Compendium of human anatomic variation. Baltimore, Urban and Schwarzenberg. 1988. pp.31.

Bianchi, B.; Ferri, A. \& Sesenna, E. Facial reanimation after nerve sacrifice in the treatment of head and neck cancer. Curr. Opin. Otolaryngol. Head Neck Surg., 20(2):114-9, 2012.

De la Cuadra-Blanco, C.; Peces-Peña, M. D.; Carvallo-De Moraes, L. O.; Herrera-Lara, M. E. \& Mérida-Velasco, J. R. Development of the platysma muscle and the superficial musculoaponeurotic system (human specimens at 8-17 weeks of development). Scien. World J., 2013:716962, 2013.

Kim, H. S.; Pae, C.; Bae, J. H.; Hu, K. S.; Chang, B. M.; Tansatit, T. \& Kim, H. J. An anatomical study of the risorius in Asians and its insertion at the modiolus. Surg. Radiol. Anat., 37(2):147-51, 2015.

Lei, T.; Cui, L.; Zhang, Y. Z.; Shi, G. J.; Peng, P.; Wang, X. H.; Xu, D. C. \& Gao, J. H. Anatomy of the transversus nuchae muscle and its relationship with the superficial musculoaponeurotic system. Plast. Reconstr. Surg., 126(3):1058-62, 2010.

Liew, S. \& Dart, A. Nonsurgical reshaping of the lower face. Aesthet. Surg. J., 28(3):251-7, 2008.

Lightoller, G. H. Facial muscles: the modiolus and muscles surrounding the rima oris with some remarks about the panniculus adiposus. J. Anat., 60(Pt. 1):1-85, 1925

Matsumine, H.; Kamei, W.; Fujii, K.; Shimizu, M.; Osada, A. \& Sakurai, H. One-stage reconstruction by dual-innervated double muscle flap transplantation with the neural interconnection between the ipsilateral masseter and contralateral facial nerve for reanimating established facial paralysis: A report of 2 cases. Microsurgery, 39(5):457-62, 2019.

Schmidt, H. M. Transversus nuchae muscle: two observations of hitherto unknown deviations of its nerve supply (author's transl). Anat. Anz., 151(2):144-50, 1982.

Schultze, F. E. Musculus Transversus Nuchae, ein Normaler Muskel am Hinterhaupte des Menschen: (Mit Abbildungen.). Rostock, Stiller'sche Hof-Buihhendling. 1865. pp.1-16.
Som, P. M. \& Naidich, T. P. Illustrated review of the embryology and development of the facial region, Part 1: Early face and lateral nasal cavities. ANJR. Am. J. Neurodiol., 34:2233-40, 2013.

Standring, S. Gray's Anatomy. The Anatomical Basis of Clinical Practice. 41st ed. New York, Elsevier, 2016. pp. 442.

Warren, R. J.; Aston, S. J. \& Mendelson, B. C. Face lift. Plast. Reconstr. Surg., 128(6):747e-64e, 2011.

Watanabe, K.; Saga, T.; Iwanaga, J.; Tabira, Y. \& Yamaki, K. I. An anatomical study of the transversus nuchae muscle: Application to better understanding occipital neuralgia. Clin. Anat., 30(1):32-8, 2017.

\section{Corresponding author:}

Nejc Umek

Institute of Anatomy

Faculty of Medicine

University of Ljubljana

Korytkova ulica 2

1000 Ljubljana

SLOVENIA

Email: nejc.umek@mf.uni-lj.si

Received: 14-04-2020

Accepted: 02-05-2020 